\title{
IDENTIFICATION OF A COMMON ANTIGENIC SITE IN THE NUCLEOCAPSID PROTEIN OF EUROPEAN AND NORTH AMERICAN ISOLATES OF PORCINE REPRODUCTIVE AND RESPIRATORY SYNDROME VIRUS
}

\author{
J. I. Casal, ${ }^{1}$ M. J. Rodriguez, ${ }^{1}$ J. Sarraseca, ${ }^{1}$ J. Garcia, ${ }^{1}$ J. Plana-Duran, ${ }^{2}$ and \\ A. Sanz ${ }^{1}$ \\ 'INGENASA \\ Hnos. Garcia Noblejas 41, 2ㅇ \\ 28037 Madrid, Spain \\ ${ }^{2}$ Lab. Sobrino \\ 17037 Vall de Bianya, Spain
}

\section{ABSTRACT}

Porcine reproductive and respiratory syndrome virus (PRRSV) nucleocapsid $(\mathrm{N})$ protein has been identified as the most immunodominant viral protein. The $\mathrm{N}$ protein genes from two PRRSV isolates Olot/91 (European) and Quebec 807/94 (North American) were cloned and expressed in Escherichia coli using the pET3x system. The antigenic structure of the PRRSV N protein was dissected using seven monoclonal antibodies (MAbs) and overlapping fragments of the protein expressed in E.coli. Three antigenic sites were found. Four MAbs recognized two discontinuous epitopes that were present in the partially folded protein or at least a large fragment comprising the first 78 residues, respectively. The other three MAbs revealed the presence of a common antigenic site localized in the central region of the protein (amino acids 50 to 66). This hydrophillic region is well conserved among different isolates of European and North American origin. However, since this epitope is not recognized by many pig sera, it is not adequate for diagnostic purposes. Moreover, none of the $\mathrm{N}$ protein fragments were able to mimic the antigenicity of the entire $\mathrm{N}$ protein. 


\section{INTRODUCTION}

Porcine reproductive and respiratory syndrome virus (PRRSV) causes an important pathology in pigs characterized by reproductive failure in sows and gilts, pneumonia and an increase in perinatal mortality (Terpstra et al., 1991). This arterivirus is now endemic in domestic pigs of the U.S. and Europe. The North American and European isolates of PRRSV represent two distinct genotypes (Suarez et al., 1996; Murtaugh et al., 1995; Meng et al., 1995; Mardassi et al., 1994), with important antigenic differences (Dea et al., 1996; Nelson et al., 1993; Wensvoort et al., 1992). However, even among different isolates of the same genotype there are considerable antigenic, genetic and pathogenic differences (Meng et al., 1996).

PRRSV is an enveloped RNA virus approximately $62 \mathrm{~nm}$ in diameter. The viral genome is a single stranded RNA of positive polarity, approximately $15 \mathrm{~kb}$ in size. The virion contains six structural proteins encoded by ORFs 2 to 7 (van Nieuwstadt et al., 1996; Meulenberg et al., 1996; Meulenberg et al., 1995). ORF7 encodes for the nucleocapsid (N) protein. Recently, we have shown that the majority of antibodies produced during the infection are specific for the N protein of PRRSV (Plana-Duran et al., 1997), which is, therefore, a suitable candidate for the detection of virus-specific antibodies and diagnosis of the disease. Since the important antigenic differences between both genotypes, the identification of antigenic sites in the $\mathrm{N}$ protein would help to prepare diagnostic assays in order to discriminate between PRRSV genotypes.

In this study we have cloned and expressed in E.coli the ORF 7 from two different PRRSV isolates: Olot/91 and Quebec 807/94. Then, we have characterized the antigenic map of the N protein of the European PRRSV Olot/91 isolate using a panel of monoclonal antibodies (MAbs) and pig antisera in combination with a collection of overlapping fragments. This study has allowed the identification of three major epitopes in the $\mathrm{N}$ protein, being one of them well conserved among the different isolates.

\section{MATERIAL AND METHODS}

\subsection{Antisera and Monoclonal Antibodies}

A collection of 48 European and 15 North American field pig sera positive for PRRSV, together with 7 MAbs specific for PRRSV Olot/91 N protein, were used for the antigenic characterization analysis of the $\mathrm{N}$ protein and its fragments. $\mathrm{N}$ protein specific MAbs were prepared from Balb/c mice immunized with semi-purified recombinant baculovirus-derived proteins (Plana-Durán et al., 1997). Protocols for immunization and the preparation of MAbs and ascitic fluids have been described previously (Sanz et al., 1985). Hybridoma supernatants were screened by ELISA and immunofluorescence assays. The isotype and subclass of each MAb were determined by ELISA using specific anti-mouse subtype antibodies (Sigma).

\subsection{PRRSV Quebec 807/94 RNA Purification and cDNA Cloning}

PRRSV Quebec 807/94 was grown in pig alveolar macrophages and semipurified as previously described (Plana-Durán et al., 1992). The semipurified virus was treated with $1 \%$ SDS and $500 \mu \mathrm{g} / \mathrm{ml}$ proteinase $\mathrm{K}$ for $1 \mathrm{~h}$ at $37^{\circ} \mathrm{C}$ for extraction of total RNA. The ORF7 cDNA was obtained by RT-PCR as previously described (Rodriguez et al., 1997). 
PCR products were cloned in phosphatase-treated SmaI-digested pMTL25. Plasmid DNA was sequenced by the dideoxynucleotide chain-termination method (Sanger et al., 1977). Protein sequence analyses were performed with PC/GENE software (Intelligenetics) and the PredictProtein mail server of EMBL (Rost, 1996).

\subsection{Cloning of PRRSV Olot/91 ORF7 Fragments in the pET3x Expression Plasmid}

The complete ORF7 coding sequences were obtained from the recombinant plasmid pPRRSV-8 (Plana-Durán et al., 1997) for Olot/91 and from pPRRSC-ORF7 for Quebec 807/94 and cloned in pET3x. The Olot/91 ORF7 fragments generated were the following: ORF 7 gene (HpaI-AflIII), A (nt -16 to 237, HpaI-TaqI), B (nt 54 to 291, PCR), C (nt 237 to 387, TaqI-AflIII), D (nt -16 to 126, HpaI-EcoNI), E (nt 126 to 237, EcoNI-TaqI) and F (nt 151 to 201, PCR) (Fig.1). For all the PCR amplifications, $50 \mathrm{ng}$ of template DNA was mixed with $800 \mathrm{ng}$ of primers (Rodriguez et al., 1997). The samples were subjected to 25 rounds of amplification under the following reaction conditions: denaturation at $94^{\circ} \mathrm{C}$ for $1 \mathrm{~min}$, annealing at $42-60^{\circ} \mathrm{C}$ for $1 \mathrm{~min}$, and extension at $72^{\circ} \mathrm{C}$ for $1 \mathrm{~min}$ plus a final extension step of $7 \mathrm{~min}$ at $72^{\circ} \mathrm{C}$. All of the fragments were recovered by $\mathrm{BamHI}$-compatible digestion and subcloned into I-digested phosphatase-treated pET3x (a,b,c) (Studier et al., 1990). The ligation mixtures were used to transform XL1 blue or DH5 competent cells. The resulting colonies were screened by digestion with appropriate restriction enzymes.

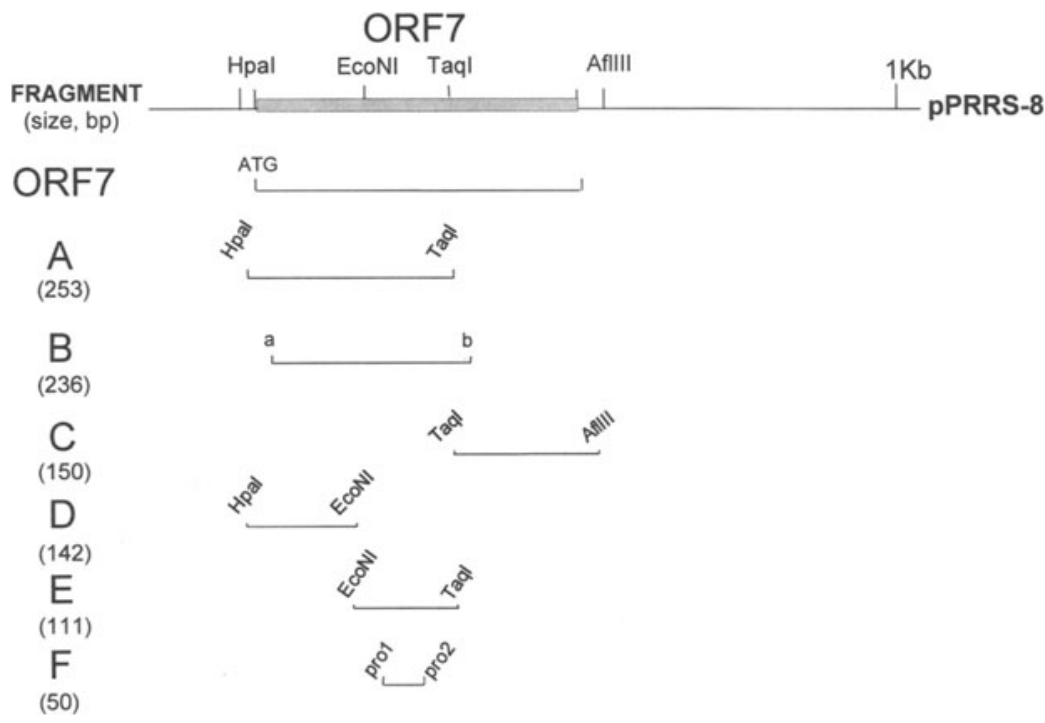

Figure 1. Map of PRRSV Olot/91 ORF 7 fragments. ORF 7 fragments were constructed as described in Materials and Methods, using conventional restriction sites or PCR. The ORF 7 is shown as a box with the restriction sites used in the fragmentation process. The lines from A to F show the restriction sites or the primers used to generate the fragments subsequently cloned in $\mathrm{pET} 3 \mathrm{x}$ expression plasmids. The size of every fragment is indicated below the letter. 
After verification of the sequence, E.coli BL21(DE3) pLysS competent cells were transformed with all the recombinant $\mathrm{pET} 3 \mathrm{x}$ plasmids.

\subsection{Growth, Induction, and Analysis of $E$. coli-Transformed Cells}

Single clones of E.coli BL21 (DE3) pLysS cells containing the recombinant pET3xderived plasmids were grown and induced with $0.4 \mathrm{mM}$ isopropyl thiogalactopyranoside (Boehringer-Mannheim). After $3 \mathrm{~h}$ induction at $37^{\circ} \mathrm{C}$, cells were centrifuged, washed twice with PBS and resuspended in a final volume of $500 \mu$ of PBS for $50 \mathrm{ml}$ of culture. Bacteria were freeze-thawed three times and then lysed by sonication. Detection of proteins was carried out by staining with Coomassie blue or by immunoblotting according to standard procedures (Harlow and Lane, 1988). Purification of the different fragments of the PRRSV N protein was carried out as described previously (Martinez-Torrecuadrada and Casal, 1995).

\subsection{ELISAs}

Microtiter 96-well plates (LabSystem) were coated overnight at $4{ }^{\circ} \mathrm{C}$ with $100 \mu \mathrm{l}$ of a dilution 1:100 of the soluble fraction obtained by guanidinium chloride-treatment of the recombinant $\mathrm{N}$ protein, or derived fragments, in $0.05 \mathrm{M}$ carbonate buffer $\mathrm{pH}$ : 9.6. Then, standard procedures were followed for the assay (Harlow and Lane, 1988). The reactivity caused by non-specific binding of sera to E.coli extracts was substracted from that of the recombinant proteins to obtain the PRRSV-specific value. The cut-off value was taken as (mean \pm 2 S.D.) of the 6 negative control sera.

For competitive ELISA, $50 \mu \mathrm{l}$ of each MAb at 10 -fold dilutions starting at $20 \mu \mathrm{g} /$ well in ZPBS- $0.05 \%$ Tween 20 were mixed and incubated with $50 \mu \mathrm{l}$ of biotin-labelled MAb for $1 \mathrm{~h}$ at $37^{\circ} \mathrm{C}$. After washing, peroxidase-labelled streptavidin (dilution 1:4,000) was added and incubated for $30 \mathrm{~min}$ at room temperature. In some cases, the competitor MAb was labelled with peroxidase instead of biotin.

For competitive ELISA among pig sera and MAbs, pig sera (dilution 1:5) were added for $1 \mathrm{~h}$ at $37^{\circ} \mathrm{C}$ and Mabs were added for $30 \mathrm{~min}$ at $37^{\circ} \mathrm{C}$. Then, plates were washed and peroxidase-labelled anti-mouse IgG added for $30 \mathrm{~min}$ at $37^{\circ} \mathrm{C}$. Finally, plates were washed and color was developed using ABTS as substrate.

\section{RESULTS}

\subsection{Monoclonal Antibodies to PRRSV N Protein}

Seven MAbs were produced that were positive for PRRSV by ELISA. The ascites fluid titers of each MAb are shown in Table 1, together with the isotype and other characteristics. All of them were positive for the native viral protein by indirect immunofluorescence and immunoperoxidase assays.

The ability of the MAbs to compete for binding to the $\mathrm{N}$ protein was tested by ELISA competition. The observed competition values were used to construct a preliminary antigenic map of the protein (Table 2). MAbs $1 \mathrm{CH} 5$ and $1 \mathrm{DH} 10$ showed a complete reciprocal competition, suggesting that the corresponding epitopes are very close or overlapping. The same complete competition was observed among 1EB9 and 1BD11 and among $1 \mathrm{AC} 7,1 \mathrm{DA} 4$ and $1 \mathrm{AG} 11$, respectively. In summary, the results were indicating the 
Table 1. Characteristics of the N protein-specific MAbs

\begin{tabular}{|c|c|c|c|c|c|}
\hline \multirow[b]{2}{*}{ Hybridome } & \multirow[b]{2}{*}{ Isotype } & \multicolumn{2}{|c|}{ ELISA (titer) } & \multicolumn{2}{|c|}{ Immunoblotting } \\
\hline & & Virus & ORF7 & Olot/91 & Quebec 807/94 \\
\hline $1 \mathrm{DH} 10$ & $\operatorname{IgG} 2 \mathrm{a}$ & $10 \mu \mathrm{g} / \mathrm{ml}$ & $100 \mathrm{ng} / \mathrm{ml}$ & - & - \\
\hline $1 \mathrm{CH} 5$ & $\operatorname{IgG} 2 \mathrm{~b}$ & $1 \mu \mathrm{g} / \mathrm{ml}$ & $10 \mathrm{ng} / \mathrm{ml}$ & $+1-$ & - \\
\hline 1EB9 & IgGI & $10 \mathrm{ng} / \mathrm{ml}$ & $\mathrm{lng} / \mathrm{ml}$ & + & - \\
\hline 1BD11 & $\operatorname{IgG} 2 \mathrm{a}$ & $10 \mathrm{ng} / \mathrm{ml}$ & $\mathrm{lng} / \mathrm{ml}$ & + & - \\
\hline $1 \mathrm{AG} 11$ & IgG1 & $1 \mu \mathrm{g} / \mathrm{ml}$ & $10 \mathrm{ng} / \mathrm{ml}$ & + & + \\
\hline $1 \mathrm{AC} 7$ & IgGI & $1 \mu \mathrm{g} / \mathrm{ml}$ & $10 \mathrm{ng} / \mathrm{ml}$ & + & + \\
\hline 1DA4 & IgG1 & $1 \mu \mathrm{g} / \mathrm{ml}$ & $10 \mathrm{ng} / \mathrm{ml}$ & + & + \\
\hline
\end{tabular}

existence of three different antigenic sites. These epitopes are quite distinct as indicated by the extremely low or null degree of competition among the MAbs of the different groups. Next step was to find the amino acid sequence corresponding to these epitopes.

\subsection{Expression of Different PRRSV ORF7 Fragments in E.coli}

A product of $370 \mathrm{bp}$ containing the complete $\mathrm{N}$ protein coding sequence of PRRSV Quebec 807/94 isolate was obtained after RT-PCR amplification of the viral RNA. After cDNA sequencing and translation to protein, it showed a high amino acid identity $(97.9 \%)$ with the Quebec isolate IAF-exp91. The only change consisted of $\mathrm{Thr}^{5}$ by $\mathrm{Asn}^{5}$. With the North American prototype isolate VR2332 (Collins et al., 1992) there was a homology of 95.2\% ( 11 mismatches out of 123 residues). The homology with the European isolate Olot/91 was much lower (i.e. $61.2 \%$ ).

Seven pET-derived recombinant plasmids were constructed containing the Olot/91 ORF7 and overlapping fragments of the N protein with various lengths from 51 to $237 \mathrm{nt}$, as shown in Fig.1. E. coli BL21 cells were transformed with the respective plasmids and induced for protein expression for $3 \mathrm{~h}$. The fusion proteins were all abundantly produced, from $0.02 \mathrm{mg}$ of fragment $\mathrm{C}$ to $0.1 \mathrm{mg}$ per ml of culture for most of the fragments. To con-

Table 2. Mapping of antigenic sites on the PRRSV N protein

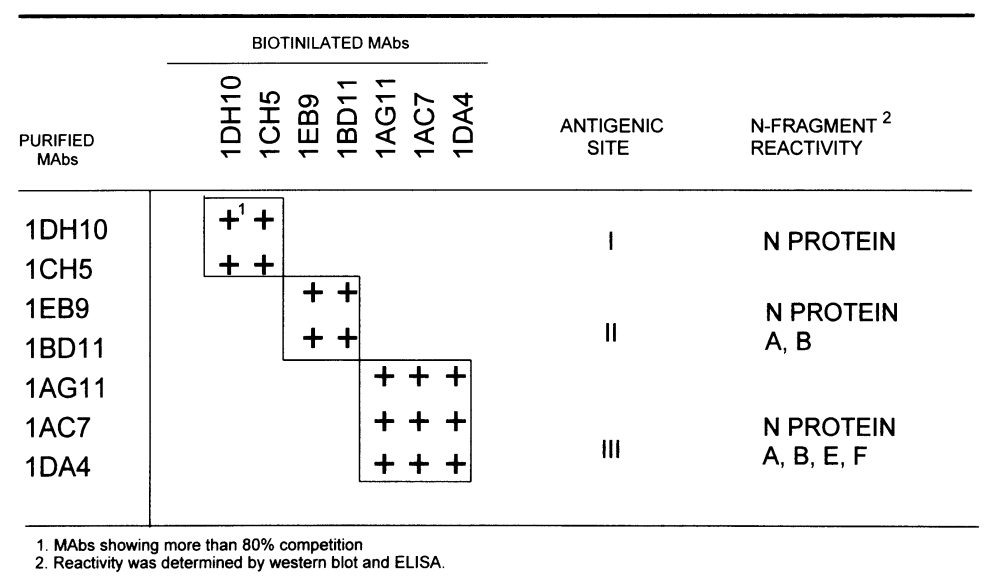


firm the identity of the fusion proteins, fragments were probed with PRRSV-positive pig antisera by immunoblotting. The binding pattern of the pig sera was variable, most of the sera reacted equally with all the fragments, but not as well as with the complete $\mathrm{N}$ protein. However, in some cases the pig sera reacted strongly with fragments A, C and D, weakly with fragment $B$ and failed to react with fragments $E$ and $F$.

Previously, we have shown that only 5 out of 7 specific MAbs reacted strongly with the $\mathrm{N}$ protein of the European isolate by immunoblotting, MAb $1 \mathrm{CH} 5$ reacted weakly and 1DH10 did not recognize the recombinant N protein (Rodriguez et al., 1997). These two MAbs may recognize conformational epitopes not properly presented in the recombinant protein. Only MAbs $1 \mathrm{AC} 7,1 \mathrm{AG} 11$ and 1DA4 recognized the N protein from the North American isolate Quebec 807/94 expressed in E.coli. By indirect ELISA, the recombinant $\mathrm{N}$ protein Olot/91 was better recognized by all the MAbs, including 1DH10. Again, the Quebec 807/94 N protein was recognized by the same three MAbs. Since they recognize the $\mathrm{N}$ protein from both isolates, European and North American, they must be reacting with a common epitope.

\subsection{Mapping of Antigenic Sites in the PRRSV N Protein}

A fine epitope mapping of the PRRSV N protein was accomplished by probing the reactivity of the different fragments of the Olot/91 ORF7 gene expressed in E.coli with the MAbs. Using immunoblotting analyses, MAbs 1AC7, 1AG11, 1DA4 reacted with fragments A, B, E and F, defining antigenic site III. Fragment F, the smallest fragment recognized, comprises the amino acid sequence 50-PEKPHFPLAAEDDIRHH-66. MAbs $1 \mathrm{BD} 11$ and 1EB9 reacted with the complete $\mathrm{N}$ protein and with the larger fragments $\mathrm{A}$ and $\mathrm{B}$, defining site II. They are probably recognizing a discontinuous epitope located in the first 78 residues of the N protein. Finally, MAbs $1 \mathrm{CH} 5$ and $1 \mathrm{DH} 10$ defined antigenic site I. The inability of these MAbs to bind the $\mathrm{N}$ protein by immunoblotting is suggesting that the recognized epitope must be discontinuous. By ELISA all of the MAbs reacted with the entire $\mathrm{N}$ protein. These data confirm that $1 \mathrm{CH} 5$ and $1 \mathrm{DH} 10$ recognize a discontinuous epitope and require the $\mathrm{N}$ protein to remain partially folded. Fragments $\mathrm{C}$ and $\mathrm{D}$, containing the $\mathrm{N}$ and $\mathrm{C}$ terminus of the protein, respectively, were not recognized by any MAb, suggesting the absence of continuous antigenic sites in these places.

\subsection{Application of the Recombinant $N$ Protein, Fragments, and MAbs in Diagnosis of PRRSV}

Finally, the utility of the recombinant polypeptides as diagnostic reagents was investigated. Both N proteins obtained from E.coli were well recognized by a collection of 48 European and 15 North American PRRSV-positive pig sera, respectively, by indirect ELISA. In all the cases the correlation with the routinely used immunoperoxidase monolayer assay (IPMA) was near $100 \%$. In contrast, none of the $\mathrm{N}$ protein truncated fragments were recognized by the complete collection of positive sera.

To improve the specificity of the assay, a competitive binding assay was set up. The results of the blocking ELISA among the MAbs and several positive pig sera are shown in Table 3. Site I MAbs $1 \mathrm{DH} 10$ and $1 \mathrm{CH} 5$ binding was completely blocked by the pig sera. Site III MAbs, recognizing the conserved linear epitopes, were partially blocked $(30-86 \%)$ and site II MAbs did not compete with the pig sera, suggesting that this site is very poorly recognized by the natural host of PRRSV. Since $1 \mathrm{DH} 10$ and $1 \mathrm{CH} 5$ are spe- 
Table 3. Blocking ELISA among

MABs and PRRSV positive

pig sera

\begin{tabular}{lr}
\hline 1DH10 & 100 \\
1CH5 & 99 \\
1EB9 & 0 \\
1BD11 & 6 \\
1AG11 & 86 \\
1 AC7 & 30 \\
1DA4 & 31 \\
\hline
\end{tabular}

${ }^{\text {'Percentage of blocking }}$

cific for the European strain, this assay would allow the discrimination among PRRSV positive sera from different genotypes.

\section{DISCUSSION}

Two different antigenic groups have been described for PRRSV, which correspond to the European and North American isolates. Newly developed vaccines based on live-attenuated North American PRRS viruses are now being widely introduced in Europe. To make a precise distinction of the origin of the virus, new diagnostic procedures have to be developed in order to discriminate between both genotypes. These procedures will have to rely on the use of marker proteins of PRRSV. The nucleocapsid protein has earlier been demonstrated to be a suitable marker for PRRSV infection, since it is the most immunodominant antigen in the pig immune response to PRRSV (Plana-Durán et al., 1997). Unfortunately, the production and purification of PRRSV antigens from tissue culture is troublesome and costly. To overcome this problem, we have described in this report the expression of the $\mathrm{N}$ protein gene in E.coli, and their use in diagnosis, extending the analysis to map antigenic regions and to identify the precise sequence of the conserved epitopes in both PRRSV genotypes.

The expression levels of the $\mathrm{N}$ protein were very high in E.coli, when expressed as a large fusion protein of $46 \mathrm{kDa}$. After solubilization with $4 \mathrm{M}$ guanidinium hydrochloride and without any further manipulation, the E.coli-derived protein could be used for diagnostic assays by simple dilution in PBS. Several truncated fragments of the N-protein were also overexpressed in E.coli and used for the epitope mapping in combination with seven specific MAbs.

From the results obtained, the MAbs could be divided into three groups, recognizing at least three different epitopes on the PRRSV N protein. MAbs $1 \mathrm{CH} 5$ and $1 \mathrm{DH} 10$ recognized a discontinuous epitope (site I) on the N protein. $1 \mathrm{CH} 5$ and $1 \mathrm{DH} 10$ compete for the same site and they were the only ones that compete efficiently with all the positive pig sera in a competition ELISA, suggesting that this epitope is probably the most immunodominant PRRSV epitope in pigs. Group II MAbs, 1BD11 and 1EB9, may also recognize a discontinuous epitope comprising several sequences inside the larger fragments $\mathrm{A}$ and $\mathrm{B}$, a region that covers the first 78 residues of the protein. Further attempts to delimitate this epitope using shorter fragments (D, E) were unsuccessful. Site III is a continuous epitope, as the MAbs react with the $\mathrm{N}$ protein after it has been denatured and with several fragments, including the short fragment F, which comprises residues 50-66. Neither site III 
MAbs nor the group II MAbs were able to compete efficiently with all the PRRSV-positive pig sera in a competition ELISA assay.

Nelson et al. (1993), Wieczorek-Krohmer et al. (1996) and Dea et al., (1996) had reported common antigenic sites among different PRRSV isolates, but no attempts to define their amino acid composition were done. Here we define the sequence of the common antigenic site in the European and American PRRSV isolates, 3 out of $7 \mathrm{~N}$ protein-specific MAbs were directed to the epitope 50-PEKPHFPLAAEDDIRHH-66 in the middle of the $\mathrm{N}$ protein. Amino acid sequence comparisons of several PRRSV isolates show that the central region (aa 50 to 90 ) of the protein is well conserved. The prediction of secondary structure and solvent accessibility indicates that the epitope 50-66 shows a high probability of being part of a random structure with a good solvent accessibility, suggesting that this epitope is exposed on the surface of the $\mathrm{N}$ protein.

The reactivity of a collection of PRRSV-specific sera with the truncated fragments by indirect ELISA was weak in general, and about one third of the pig sera did not react with any of the fragments. Therefore fragment $F$, containing the common epitope, does not seem a suitable reagent for diagnostic purposes. The fact that the conserved, linear epitopes are not immunodominant would explain the lack of cross-reactivity for the $\mathrm{N}$-protein among positive pig sera of different origin. This explanation is supported by the fact that MAbs 1CH5 and 1DH10, which compete efficiently with all the European-positive sera, recognize only the Olot/91 N protein, but not Quebec 807/94. The most immunodominant epitope, which is recognized by all the European pig sera and by the MAbs $1 \mathrm{CH} 5$ and $1 \mathrm{DH} 10$, is a variable and conformation-dependent epitope. As a consequence, only the entire $\mathrm{N}$ protein, expressed in E.coli, seems to be a suitable reagent for diagnostic purposes. It is expressed at very high levels and is easy to purify. In summary, the combination of the recombinant $\mathrm{N}$ protein and the MAbs $1 \mathrm{DH} 10$ and $1 \mathrm{CH} 5$ provides a powerful tool for a rapid and specific diagnosis of PRRSV and paves the way to a new test to differentiate infections caused by distinct PRRSV genotypes.

\section{ACKNOWLEDGMENTS}

This work was partially funded by a grant (351/96) of the Spanish Ministry of Industry and Energy.

\section{REFERENCES}

Collins, J.E., Benfield D.A., Christianson W.T., Harris J.C., Hennings, D.P., Shaw, S.M. Goyal, S.M., McCullough, S., Morrisson, R.B., Joo H.S, Gorcyca D. and Chladek D. W., 1992, Isolation of swine infertility and respiratory syndrome virus (isolate ATCC VR-2332) in North America and experimental reproduction in gnotobiotic pigs, J. Vet. Diag. Inves. 4: 117-126.

Dea, S., Gagnon, C.A., Mardassi, H. and Milane G., 1996, Antigenic variability among North American and European strains of Porcine Reproductive and Respiratory Syndrome Virus as defined by monoclonal antibodies to the matrix protein, J. Clin. Microbiol. 34: 1488-1493.

Harlow, E. and Lane, D., 1988, Antibodies, A laboratory manual, Cold Spring Harbor Laboratory, Cold Spring Harbor, New York.

Mardassi, H., Mounir, S. and Dea S., 1994, Identification of major differences in the nucleocapsid protein genes of a Québec strain and European strains of porcine and respiratory syndrome virus, J. Gen. Virol. 75: 681-685.

Mardassi, H., Mounir S. and Dea S., 1994, Identification of major differences in the nucleocapsid protein genes of a Quebec strain and European strains of porcine reproductive and respiratory syndrome virus, J. Gen. Virol. 75: $681-685$. 
Martinez-Torrecuadrada, J.L. and Casal J.I., 1995, Identification of a linear neutralization domain in the protein VP2 of African horsesickness Virus, Virology 210: 391-399.

Meng, X.J., Paul, P.S, Halbur, P.G. and Lum, M.A., 1995, Phylogenetic analysis of the putative M (ORF6 and N (ORF7) genes of porcine reproductive and respiratory syndrome virus (PRRSV): implication for the existence of two genotypes of PRRSV in the US and Europe, Arch. Virol. 140: 745-755.

Meng, X.J., Paul, P.S, Halbur, P.G. and Morozov I., 1996, Sequence comparison of ORFs 2 to 5 of low and high virulence United States isolates of porcine reproductive and respiratory syndrome virus, J. Gen. Virol. 76:3181-3188.

Meulenberg, J.J., Hulst, M.M., De Meijer, E.J., Moonen, P.L.J.M., Den Besten, A.P., De Kluyver, E.P., Wensvoort, G. and Moormann, R.J.M., 1993, Lelystad Virus, the causative agent of porcine epidemic abortion and respiratory syndrome (PEARS), is related to LDV and EAV, Virology 192: 62-72.

Meulenberg, J., Den Besten, A.P., De Kluyver, E.P., Moorman, R.J.M., Schaaper, W.M.M. and Wensvoort, G., 1995b, Characterization of proteins encoded by ORFs 2 to 7 of Lelystad Virus, Virology 206: 155-163.

Meulenberg, J.J.M. and Petersen Den Besten, A., 1996, Identification and characterization of a sixth structural protein of Lelystad Virus: The glycoprotein $\mathrm{GP}_{2}$ encoded by ORF2 is incorporated in virus particles, Virology 225: 44-51.

Murtaugh, M.P., Elam, M.R. and Kakach L.T., 1995, Comparison of the structural protein coding sequences of the VR-2332 and Lelystad virus strains of the PRRS virus, Arch. Virol. 140: 1451-1460.

Nelson, E. A., Christopher-Hennings, J., Drew, T., Wensvoort, G., Collins, J.E. and Benfield, D.A., 1993, Differentiation of United States and European isolates of porcine reproductive and respiratory syndrome virus by monoclonal antibodies, J. Clin. Microbiol. 31: 3184-3189.

Plana-Duran, J., Vayreda, M., Vilarasa, J.L., Bastons, M., Rosell, R., Martinez, M., San Gabriel, A., Pujols, J., Badiola, J.L., Ramos, J.A and Domingo M., 1992, Porcine epidemic abortion and respiratory syndrome (mystery swine disease, Isolation in Spain of the causative agent and experimental reproduction of the disease, Vet. Microbiol. 33, 203-211.

Plana-Duran, J., Climent, I., Sarraseca, J., Urniza, A., Cortés E., Vela C. and Casal, J.I., 1997, Baculovirus expression of proteins of Porcine Reproductive and Respiratory Syndrome Virus strain Olot/91. Involvement of ORF3 and ORF 5 proteins in protection, Virus Genes. 14: 19-29.

Rodriguez, M.J., Sarraseca, J., Garcia, J., Sanz, A., Plana-Duran, J and Casal, J.I., 1997, Epitope mapping of the nucleocapsid protein of European and North American isolates of Porcine Reproductive and Respiratory Syndrome Virus, J. Gen. Virol. In press.

Rost, B., 1996, PHD: predicting one-dimensional protein structure by profile based neural networks, Meth. Enzymol. 266: 525-539.

Sanger, F., Nicklen, S. and Coulson, A.R., 1977, DNA sequencing with chain terminating inhibitors, Proc. Nat. Acad. Sci. USA 74: 5463-5467.

Sanz, A., Garcia-Barreno, B., Nogal, M.L., Viñuela, E. and Enjuanes, L., 1985, Monoclonal antibodies specific for African swine fever virus proteins, J. Virol. 54: 199-206.

Studier, F.W., Rosenberg, A.H., Dunn, J.J. and Dubendorff, J.W., 1990, Use of T7 RNA polymerase to direct expression of cloned genes, Met. Enzymol. 185: 60-89.

Suarez, P., Zardoya, R., Martín, M.J., Prieto, C., Dopazo, J., Solana, A. and Castro, J.M., 1996, Phylogenetic relationships of European strains of porcine reproductive and respiratory syndrome virus (PRRSV) inferred from DNA sequences of putative ORF-5 and ORF-7 genes, Virus Res. 42: 159-165.

Terpstra, C., Wensvoort, G. and Pol, J.M.A., 1991, Experimental reproduction of porcine epidemic abortion and respiratory syndrome (mystery swine disease) by infection with Lelystad virus: KochEs postulates fulfilled, Vet. Q. 13: 131-136.

Van Nieuwstadt, A.P., Meulenberg, J.J.M., van Essen-Zanderbergen A., Petersen Den Besten, A., Bende, R.J., Moorman, R.J.M. and Wensvoort, G., 1996, Proteins encoded by open reading frames 3 and 4 of the genome of Lelystad virus (Arteriviridae) are structural proteins of the virion, J. Virol. 70: 4767-4772.

Wensvoort, G., De Kluyver, E.P., Luijtze, E.A., Den Besten, A.P., Harris,L., Collins, J.E., Christianson, W.T. and Chladek, D., 1992, Antigenic comparison of Lelystad Virus and swine respiratory syndrome (SIRS) virus, J. Vet. Diagn. Invest. 4: 134-138.

Wieczorek-Krohmer M., Weiland F., Conzelman, K., Kohl D., Visser N., Van Woensel, P., Thiel, H.-J. and Weiland, E., 1996, Porcine reproductive and respiratory syndrome virus (PRRSV): Monoclonal antibodies detect common epitopes on two viral proteins of European and U.S. isolates, Vet. Microbiol. 51: 257-266. 